\title{
SUID-AFRIKA EN SY EKONOMIES SELFSTANDIGE
}

\section{TOEKOMS}

Waarom streef nasies onafhanklikheid so naarstiglik na? Is onafhanklikheid terselfdertyd 'n woord sonder werklik praktiese betekenis in die wêreld van vandag?

Dit wil voorkom asof die ideale van sommige vir „één wêreldstaat" tans verder en verder op die agtergrond skuif. Inteendeel is 'n opwelling van nasionalisme duidelik waarneembaar in die meeste dele van die wêreld. Selfs die ideaal van ,'n Verenigde Europa" skyn, afgesien van groter ekonomiese samewerking, vandag minder van ' $n$ werklikheid te wees as ooit tevore. Dit skyn onmoontlik te wees om die eie nasionale trots van 'n erkende volk sonder meer uit te wis. Onafhanklikheid bly dus 'n begrip wat in die ware sin van die woord groot betekenis vir elke volk van naam inhou.

'n Verdere belangrike vraag is: Word onafhanklikheid van politieke of staatkundige aard te veel beklemtoon en word daar te min waarde geheg aan ekonomiese selfstandigheid?

Dit is belangrik dat ons hierdie begrippe duidelik onder die soeklig stel, omdat die nastrewe daarvan spesifieke optredes verg wat spesifieke gevolge en verantwoordelikhede vir 'n land en 'n volk inhou.

Bykans elke land „kwalifiseer" vandag vir die meer populêre begrip van onafhanklikheid, veral omdat staatkundige onafhanklikheid vandag meesal "om 'n konferensietafel" verkry word. So 'n land se politieke of staatkundige onafhanklikheid is teoreties vooraf gewaarborg. Dit verg geen besondere inspanning, vernuf of beplanning nie. Die druk van die „demokratiese" wêreld en politieke ambisies verseker sukses en, indien nodig, sorg daarna vir die mense. Maar is hulle nie onafhanklik net in woord en nie werklik in daad nie?

\section{Voorbeelde}

Daar is talle voorbeelde van sulke lande wat, lank gelede en onlangs, so hulle staatkundige onafhanklikheid ten volle verkry het. Die vraag is, hoeveel van hulle, van Nigerië en die Malagasiese Republiek tot Zambië en ander state in SuiderAfrika, om veral van hierdie kontinent te praat, is werklik selfstandig en kan op eie voete staan? Hoe vergelyk Suid-Afrika 
met hierdie groep en die ander ouer lande?

Die praktiese waarheid is dat politieke onafhanklikheid slegs ' $n$ verandering in staatkundige en ideologiese samestelling vir ' $n$ land beteken en nog geensins ontwikkeling verteenwoordig of ' $n$ aanduiding is dat só ' $n$ land ,op eie bene staan of kan staan nie".

\section{Wes-Duitsland en Japan}

'n Verdere interessante vergelyking is met lande wat selfs nie algehele politieke onafhanklikheid besit nie. Hoe sterk staan hulle? Waar plaas ons Wes-Duitsland en Japan?

Hier wil ek die stelling maak dat: Ware onafhanklikheid slegs bereik kan word deur ekonomiese selfstandigheid! Hierdie stelling kan seker nie beter geillustreer word as om die posisie van en die rol wat vandag deur Wes-Duitsland in die wêreld vervul word, in oënskou te neem nie:

Skaars 25 jaar gelede was Wes-Duitsland in puin, die land en nywerheid verwoes en bykans die helfte van sy vooroorlogse gebied van hom weggeneem. Hy was in totale ekonomiese chaos met onbeteuelde inflasie. Vandag praat almal van Wes-Duits. land as 'n „wonderwerk" en die grootste krag in Europa. Ekonomies staan hy alleen, heelbo. Hy het, met die uitsondering van kernwapens, die sterkste militêre mag in Wes-Europa, dic grootste industriële masjien en is potensieel in die posisie om die sleutelrol in wêrelddiplomasie te vervul.

Nieteenstaande sy politicke afhanklikheid en die geweldige druk wat sy Westerse bondgenote uitoefen, het hy onlangs selfstandig geweier om sy geldeenheid te herwaardeer. Hierdie voorval stel dit duidelik: Wes-Duitsland het in baie opsigte en in ' $n$ verbasende kort tydperk die kragtigste land in Europa geword - en sal dit volgens alle aanduidings vir 'n lang tyd bly. Hy het selfs 'n krag geword waarmee die magtigste land ter wêreld, die V.S.A., in belangrike opsigte rekening moet hou. Die vraag is: Hoe is dit moontrik?

Wat kan ons in Suid-Afrika daaruit leer? Die antwoord is eintlik heel eenvoudig. Ná die oorlog het die mense van Duitsland geen ander keuse gehad as om al hul krag, vernuf en energie in die eerste plek aan die ekonomiese opbou en die ekonomiese selfstandigheid van hul land te bestee nie. In hierdie proses moes hulle die politieke aspirasies aan Frankryk 
en die politieke illusies aan Brittanje oorlaat.

Ek glo dat die sukses van, byvoorbeeld, Wes-Duitsland nie behaal is omdat sy mense 'n ,spesiale, wonderlike ras" met groter brein- of werkkrag is nie, maar eenvoudig omdat hulle doelgerig en geinspireerd sekere ideale vir hulself gestel en nagestreef het en bereid was om daarvoor te werk.

\section{Ware onafhanklikheid}

Met hierdie as agtergrond-perspektief, wanneer kan 'n land werklik van ware onafhanklikheid en selfstandigheid praat? Wat is die aanduidings, watter lande gaan die toekomstige leiers in die wêreld wees? Die vorige, magtige Britse ryk, die oorwinnaars van 25 jaar gelede, is sedertdien, prakties gesproke, nog steeds op die "terugpad" as 'n volk. Die magtige V.S.A. toon vandag baie tekens van 'n volk wat begin om sy „glans" te verloor en terug te val van sy vroeëre hoë standaarde van gehalte en diens. Terselfdertyd sien ons hoedat 'n land soos Japan elke dag meer skitter in groei en briljantheid op feitlik elke gebied.

\section{Suid-Afrika}

Suid-Afrika het sy volle politieke onafhanklikheid in werk. likheid eers in 1961, lank ná Ghana in 1957, verkry maar tog lank v6or ' $n$ land soos Kanada wat vandag nog ' $n$ dominium is.

Nieteenstaande Ghana en ander Afrika-lande se vroeë politieke „volwassenheid" is daar geen vergelyking tussen hulle ekonomiese ontwikkeling en volkswelvaart en dié van SuidAfrika nie. Terselfdertyd moet die vraag tog onder die soeklig gestel word of Kanada, bv. in sy bankwese, en ook Australië nie in belangrike opsigte meer selfstandig as Suid-Afrika is nie. Kanada het egter weer een ander belangrike en groot probleem: die Amerikaners beheer prakties gesproke aansienlik meer as die helfte van sy nywerheidswese. Dit is algemeen bekend dat hierdie 'n ,seer plek" van groot kommer en 'n hindernis vir die Kanadese is.

Staatkundig het Suid-Afrika dus sy doelwit volkome bereik. Ekonomies het sy ontwikkeling ook ver en mooi gevorder en word ons vandag as die „reus van Afrika” beskryf. Maar kan ons nie werklik reeds selfvoldaan terugsit en van "ware onafhanklikheid" of te wel, selfstandigheid praat? 


\section{Die pad vorentoe}

Met ons huidige stadium van ontwikkeling op die pad van selfstandigheid is dit logies om te vra watter strewe en ideale of alternatiewe ideale nou vir ons in Suid-Afrika oorbly?

Met ons besondere omstandighede en besondere probleme soos die veelrassige samestelling van ons bevolking, die getalle en die graad van hulle ontwikkeling en hulle aspirasies, moet ons daaraan dink of ons 'n toekomstige „klein" Switserland wil wees of liewers 'n kragtige, ekonomiese en selfs politieke leier soos die V.S.A.

\section{Net een alternatief}

Vir my persoonlik is daar eintlik net een alternatief en dit is om te werk vir die maksimum ekonomiese ontwikkeling en uitbreiding waartoe ons in staat is en wat sal sorg vir werkgeleenthede en 'n steeds hoër lewenstandaard vir almal. Solank daar mense is wat honger ly, sal die ander, hoe welvarend ook al, nie gerus kan slaap nie.

Om dit baie kortliks te stel, sou ek dus ons ideaal soos volg omskryf: Om doelgerig daarna te strewe en daarvoor te werk om Suid-Afrika tot die hoogste en absolute mate van ekonomiese en finansiële selfstandigheid en weerbaarheid uit te bou, met 'n hoë en steeds hoër lewenstandaard vir al sy mense. Dit is die mooiste ideaal en ons grootste taak!

Ek wil dit egter duidelik stel dat die strewe na volkome onafhanklikheid nie gesien moet word as 'n ,inwaartse beweging" of die trek van 'n laer tot isolasie nie. Inteendeel, juis die teenoorgestelde word bedoel. Dit is 'n strewe tot 'n doel om 'n groter uitwaartse rol te speel.

Dit is alleen wanneer 'n land „inwaarts" sterk is dat hy „uitwaarts" ' $n$ belangrike rol kan speel. Maar, is dit wel binne ons bereik? Om ekonomies selfstandig te kan wees, moet 'n land aan sekere basiese norme en standaarde kan voldoen. Hierdie voorvereistes waaraan voldoen moet word, is hoofsaaklik die volgende:

$\diamond$ Die vermoë om in die voedsel- en ander noodsaaklike lewensbehoeftes van sy volk te kan voorsien.

$\diamond$ Kundige en voldoende arbeid, asook die beskikbaarheid van ondernemerstalent. 
$\diamond$ Die aanwesigheid of bekombaarheid van basiese grondstowwe en sekere strategiese minerale.

$\diamond$ 'n Gesonde infra-struktuur waarop ontwikkeling uitgebou kan word - krag, vervoer, kommunikasie, en watervoorsiening.

$\diamond$ Die beskikbaarheid van besparings en kapitaal om ontwikkeling te finansier en die aanwesigheid van eie finansiële instellings om fondse doeltreffend te kanaliseer.

Aan hierdie norme gemeet, besit ons dit wat nodig is om die ideaal van selfstandigheid na te streef? Die antwoord is myns insiens ' $n$ besliste ja! Onder andere omdat ons bevoorreg is met uitstekende strategiese voordele soos:

(a) In die opsig van voedsel en noodsaaklike lewensbehoeftes kan Suid-Afrika grootliks as selfversorgend en selfstandig beskou word, veral mits ons vroegtydig die nodige stappe doen in verband met langtermyn-waterbewaring en -voorsiening in Suid-Afrika.

Hoewel die landbousektor periodiek gebuk gaan onder droogtes en ook ander probleme ondervind, was die Republiek in staat om sy uitvoer van voedselprodukte gedurende die afgelope 20 jaar vier keer vinniger te laat toeneem as sy invoer. Hierbenewens het ons totale binnelandse verbruik van voedsel gedurende hierdie tydperk met slegs $80 \%$ toegeneem terwyl ons produksie met soveel as $160 \%$ gestyg het. M.a.w. die produksie van voedsel styg steeds vinniger as die plaaslike behoeftes, en uitvoerbare oorskotte van landbouprodukte is gevolglik aan die toeneem.

Geen wonder dus dat Suid-Afrika, ten spyte daarvan dat hy nie ' $n$ landbouland by uitnemendheid is nie, nogtans daarop kan roem dat sy bevolking amptelik onder die 12 besgevoede nasies in die wêreld tel. Op hierdie gebied lyk die toekoms dus gunstig.

(b) Wat arbeid betref, het ons 'n vinnig groeiende bevolking wat minstens gedurende die volgende 30 jaar meer as sal verdubbel van die huidige 19 miljoen tot minstens 45 miljoen.

Arbeidskragtekort is ' $n$ kenmerkende verskynsel wat internasionaal deur alle snelgroeiende lande ondervind word. By ons is geskoolde arbeidskrag ook ons heel ernstigste knelpunt. Dit hoef egter nie as 'n onoorkombare knelpunt aanvaar te word 
nie mits 'n positiewe benadering gevolg en die nodige drastiese stappe betyds gedoen word om dit aan te vul.

Persoonlik bepleit ek al jare lank baie meer grootskaalse immigrasie as die huidige 30,000 netto per jaar. Myns insiens het ons nie alleen die arbeidskrag en die groter getalle dringend nodig om ons beoogde uitbreiding te help aanvul nie, maar ewe belangrik vorm dit 'n belangrike gedeelte van die meer komplekse-formule tot die langtermyn-oplossing van onder andere ons belangrike rassevraagstuk in hierdie land. Terselfdertyd gaan immigrasie gepaard met die beskikbaarstelling van addisionele kundigheid (,,know-how") en ondernemerstalent.

(c) Wat basiese grondstowwe en ander strategiese minerale betref, word Suid-Afrika deur baie as „die wêreld se skatkis" beskou. Dit is in baie opsigte waar.

Weens 'n ,geologiese wonderwerk" beklee ons vandag die vierde plek in die totale jaarlikse wêreldproduksie van minerale, en kon Suid-Afrika sedert die begin van hierdie eeu sy produksie elke tien jaar verdubbel.

Benewens sy goud - ons land lewer $73.3 \%$ van die vrye wêreld se goud - kan Suid-Afrika, weens sy posisie as die wêreld se vernaamste of een van die vernaamste produsente van sulke materiaal, selfs die toevoer beheer en die pryse van 'n groot aantal minerale reël. Laat my toe om net enkeles te noem. Suid-Afrika is vandag:

$\diamond$ die wêreld se grootste produsent van sierdiamante, platina en binnekort ook geëlektrofiseerde koper, ferro-chroom en ferro-mangaan;

$\diamond$ een van die twee grootste produsente van mangaan, chroom, antimoon en litium;

$\diamond$ op twee na die grootste produsent van asbes, vanadium en uraan;

$\diamond$ op vier na die grootste produsent van nikkel;

en

$\diamond$ onder die eerste tien produsente van kadmium, berillium, bismut, grafiet en magnesiet.

Sonder sommige van hierdie strategiese minerale kan die wêreld se voorraadposisie in chaos gedompel word: en met die tegnologiese vooruitgang van die moderne wetenskap word daagliks nuwe behoeftes aan meer soorte materiale ondervind. Terwyl ons mineraalopbrengs gedurende die afgelope 80 
jaar reeds $\mathrm{R} 17,000$ miljoen opgelewer het, kan verwag word dat ons minerale in die toekoms nog groter rykdom sal bring - nie alleen vanweë die verwagte toename in aanvraag nie, maar veral weens ons reserwes, byvoorbeeld:

$\diamond$ chroom, waarvan twee derdes van die vrye wêreld se reserwes in Suid-Afrika aangetref word, wat tewens een van die enigste twee lande is wat produksie in die toekoms sal kan handhaaf; en

$\diamond$ germanium, vandag een van die mees strategiese metale, wat net in drie lande buite die Ystergordyn gevind word.

In kort kan dus gesê word aat ons een van die ryks bedeelde en gevolglik „onafhanklikste” lande in die wêreld is wat natuurlike hulpbronne betref, met die belangrike uitsondering van olie waarna ek later weer sal terugkeer.

(d) Suid-Afrika beskik reeds oor 'n redelik ontwikkelde infra-struktuur waarop hy sy verdere ontwikkeling op die pad na selfstandigheid kan uitbou:

Eerstens het ons voldoende kragbronne soos steenkool vir grootskaalse nywerheidsontwikkeling. Die enigste swak skakel waarmee ons hier te kampe het, is dat ons vir ons olieverbruik grootliks van die buitewêreld afhanklik is. Stappe is egter reeds gedoen en ons spandeer tans groot somme geld aan die soek na hierdie kragbron in Suid-Afrika. Daar bestaan myns insiens redelike verwagtings dat ons dit behoort te vind, maar indien nie, dan - met Sasol alreeds as 'n begin en met verdere eenhede as alternatief - behoort ons op hierdie gebied die toekoms ook vol moed tegemoet te kan gaan, al is dit dan teen 'n ,prys". Met nog 'n Sasol behoort dit moontlik te wees om in elk geval onder noodtoestande en met besparingsmaatreëls, redelik selfstandig te kan staan.

Met 'n wêreldsurplus van olie is dit in elk geval hoogs onwaarskynlik dat ru-olie nie in die toekoms vrylik bekombaar sal wees nie. Die raffinering en verdere verwerking daarvan kan reeds op hierdie stadium deur ons eie installasies onderneem word. Die enigste werklike probleem is gevolglik die vervoer daarvan. Hier is dus 'n groter eie tenkvloot nodig waaraan tans ook aandag geskenk word.

\section{Kragopwekking}

Wat die opwekking van krag betref, is Suid-Afrika reeds 
een van die voorste lande in die wêreld. Met 35,000 miljoen eenhede per jaar of 1,900 per hoof van ons totale bevolking, ontwikkel ons $57 \%$ van die totale krag in Afrika of 20 keer die gemiddelde syfer vir die res van Afrika. Terselfdertyd is ons verbruik per kapita reeds meer as dié van ouer en hoogs geindustrialiseerde lande soos Italië en Japan en gelyk aan dié van Brittanje slegs 7 jaar gelede.

Nieteenstaande hierdie huidige hoë kragverbruik word ook reeds vir toekomstige verbruik voorsiening gemaak tot dié mate dat dit ten minste elke 9 jaar sal verdubbel en dat dit sal kan styg tot 300,000 miljoen eenhede teen die jaar 2,000 in vergelyking met die huidige verbruik van 35,000 miljoen eenhede.

Tweedens, wat 'n land se vervoer- en kommunikasiestelsel betref, is dit veral belangrik uit 'n weerbaarheidsoogpunt.

Hoewel Suid-Afrika nie oor bevaarbare riviere beskik nie, vorm vervoer nie ' $n$ belangrike probleem in ons ekonomiese ontwikkeling nie, aangesien ons land alreeds goed bedien word deur 'n uitgebreide spoor-, lug- en padnetwerk. Dit, tesame met strategiese geleë hawens aan sy 2,800 myl lange kus, maak dat Suid-Afrika goed vergelyk met die beste elders.

Die enigste relatiewe swak skakel hier is ten opsigte van sekere toerusting, veral lugvaart, waar ons nog grootliks van die buiteland afhanklik is

(e) Wat besparing en fondse vir ontwikkeling betref, kan ons reeds onafhanklik van die buitewêreld redelik vinnig op ons eie ontwikkel om 'n steeds hoër lewenstandaard aan al ons mense te voorsien.

Suid-Afrikaners word algemeen beskou as die wêreld se grootste spaarders. Ons spaar tans $26.2 \%$ van ons Bruto Binnelandse Produk, wat heelwat meer is as die $23.7 \%$ in 1960 wat op sigself baie gunstig vergelyk het met die gemiddelde van ander ontwikkelde lande.

Gedurende die tydperk van 1960 tot 1967 het ons totale binnelandse besparing R13,975 miljoen beloop, en in vergelyking met die netto buitelandse kapitaalvloei van $.8 \%$ gedurende hierdie tydperk is $99.2 \%$ van ons behoeftes dus uit eie bronne gefinansier.

\section{Internasionale geldmarkte}

Ek wil dit egter baie duidelik stel dat ek glo dat ons nog- 
tans in die internasionale geldmarkte teenwoordig moet wees en ons goeie kredietwaardigheid daar moet behou en versterk. Met behulp van verdere buitelandse kapitaal sal ons ons tempo van ontwikkeling kan versnel, wat onder gegewe omstandighede baie wenslik kan wees.

Suid-Afrika kan en behoort ook van nou af aan sy posisie as 'n kapitaal-uitvoerland te begin dink.

Aanvullend tot die beskikbaarheid van kapitaal is dit belangrik dat die praktiese beheer van ons strategiese nywerhede en strategiese diensindustrieë soos die bank- en assuransiewese plaaslik gevind word. Hier, moet ons erken, bestaan daar nog swak skakels:

\section{Bankwese}

Waar die bankwese in ons land tot nog onlangs toe feitlik uitsluitlik buitelands beheer was, het Suid-Afrikaans beheerde banke in die laaste paar dekades groot vordering gemaak tot die ideaal van oorwegend Suid-Afrikaanse bankwese.

In 1947 was ongeveer $94 \%$ van die totale deposito's van alle banke by buitelands beheerde bankinstellings teenoor slegs $6 \%$ in die geval van eg Suid-Afrikaanse instellings. Sedertdien en tot en met ongeveer 1965 toe die plafon op die groei van banke geplaas is, het die aandeel van die buitelands beheerde banke gedaal na ongeveer $52 \%$ en die van Suid-Afrikaans beheerde banke gestyg na $48 \%$.

Wat kapitaal en reserwes betref, het Suid-Afrikaans beheerde banke gevorder tot hulle sowat $60 \%$ van die totaal verteenwoordig het. Die toepassing van die besondere vorm van 'n plafon op bankkrediet wat die afgelope 4 jaar toegepas is, het egter veroorsaak dat in die tydperk die verhoudings tussen die twee groepe noodwendig $\mathrm{min}$ of meer staties gebly het.

Lande soos Kanada en Australië, ook die magtige V.S.A. volg 'n baie meer "nasionale" beleid op hierdie gebied. Eersgenoemde laat byvoorbeeld nie buitelandse banke toe nie en in die V.S.A. word maar net in sowat 8 van sy 50 state 'n "heel afgewaterde vorm van buitelandse bankwese" toegelaat, meesal net verteenwoordigende kantore wat nie toegelaat word om deposito's te werf en gewone binnelandse bankdienste te verskaf nie. 


\section{Versekeringsveld}

In die versekeringsveld bly die toestande die laaste twintig jaar ook bykans onveranderd. Sewentig persent van alle lewensversekering word wel deur plaaslik beheerde organisasies behartig, maar in die baie belangrike en strategiese korttermynversekeringsveld is slegs $30 \%$ in die hande van Suid-Afrikaans beheerde organisasies.

\section{Ander strategiese voordele}

Afgesien van genoemde belangrike vereistes tot selfstandigheid is Suid-Afrika in die besondere posisie om ook reeds te beskik oor:

$\diamond$ 'n Goed gevestigde en moderne nywerheidsmasjien.

$\diamond$ Goeie sakekennis en -vernuf. Ons vergelyk reeds goed wat moderne metodes en doeltreffendheid betref. Veel meer kan egter op die gebied van meganisasie, outomatisasie en ander tegnologiese ontwikkelings gedoen word.

\section{Binnelandse mark en uitvoerbedryf}

'n Ontwikkelende binnelandse mark wat volgens raming gedurende die volgende 30 jaar minstens sesvoudig sal toeneem tot ' $n$ koopkrag van meer as R35,000 miljoen in terme van vandag se geld. As ook in aanmerking geneem word dat ons hoop om die lewenstandaard van die meer ontwikkelde gedeelte van ons bevolking oor hierdie tydperk minstens weer te verdubbel en dié van die onderontwikkelde gedeeltes minstens te verdriedubbel, dan kry ons nie alleen 'n aanduiding van die markpotensiaal plaaslik nie, maar ook van 'n gesonde en noodsaaklike grondslag vir die suksesvolle bevordering van ons uitvoerbedryf.

Hierbenewens geniet Suid-Afrika ook die bykomstige voordeel van sy strategiese ligging tussen Oos en Wes. Dit hou wel gevare in, maar kan groot voordele beteken soos in die jongste tyd bewys is in verband met skeepvaart om ons kuste.

\section{„Springplanke”}

Verder verskaf dit aan ons 'n natuurlike ,springplank" vir deelname aan die handel en nywerheidsontwikkeling in 'n groot deel van Afrika en die res van die wêreld. 


\section{Toerisme}

Laastens verskaf ons land se natuurlike skoonheid en gunstige klimaat, tesame met verdere verwagte ontwikkelings in vervoer en kommunikasie, 'n ontsaglike ryk potensiaal vir toerisme, mits ons ook hier meer aggressief optree en 'n doelbewuste "totale bemarkingsbenadering" toepas

\section{Aksieprogram vir sukses}

Nou, waar Suid-Afrika dus baie duidelik oor die inherente vermoë beskik om saam met die toonaangewende lande in die wêreld grootliks ekonomies en finansieel selfstandig te kan wees, is dit belangrik om vas te stel wat ons sukses, al dan nie, sal bepaal en wat ons aksieprogram moet wees.

\section{Werk - skeppend en fisies}

Gedagtig aan Duitsland, Japan, Israel en ook ander deur die eeue, gaan hierdie ideaal nie deur ons „om 'n konferensietafel" bereik word nie; ook nie op die sportveld of by vakansieoorde nie. Ook geen organisasie van volkere sal of kan dit vir ons gee nie. Ons sal die pad daarnatoe moet vind, selfs self moet bou en daarvoor moet werk - skeppend en fisies!

Ek glo dat ons ons sukses onder andere veral in die volge:ade sal vind:

A. Uns menslike materiaal - die ideale, ondernemingsgees en werkvermoë van ons mense. Kan ons weer uit die geskiedenis en uit die lesse van ander leer? Die Ooste miskien?

Japan het bykans geen natuurlike hulpbronne nie; geografies is hy kleiner as die meeste van die 50 state van die V.S.A en minder as een derde van die totale oppervlakte van die Republiek; en verder is hy ' $n$ land wat deur die wêreld verstote, eeue lank in isolasie gelewe het. Slegs ongeveer 20 jaar gelede is daar nog op hom neergekyk as 'n agterlike land van nabootsers en swak produkkwaliteite. Ná sy neerlaag in die vorige oorlog en die slagting van Hiroshima en Nagasaki het hy egter vinnig ontwikkel en is hy vandag reeds een van die grootste nywerheidslande in die wêreld met 'n kragtige produksiemasjien bekend vir gehalte van die beste. Vandag bou hy meer as die helfte van die wêreld se skepe, dus by verre 
die grootste skeepsbouland en druk hy ander vervaardigers van motors, elektroniese toerusting en soortgelyke produkte uit hulle tradisionele markte. Hy het reeds Wes-Duitsland verbygesteek en is vinnig besig om die V.S.A. in te haal.

Ook ons moet:

(i) Weet waarheen ons wil gaan. Dit beteken doelbewuste beplanning deur middel van die daarstelling van minimum doelwitte en voortdurende aanpassings daarvan in die lig van die praktiese omstandighede.

(ii) Die sakewêreld: Die tekens van die tyd reg lees en ons beplanning daarvolgens instel. Ons moet weet waar en in watter rigtings die grootste moontlikheid bestaan om toekomstige welvaart te skep. Hier is dit waar ek die sakewêreld so belangrik beskou en dat ons as volk baie meer sake-georiënteerd opgelei moet word.

(iii) Streef na briljantheid: Streef na die hoogste briljantheid en doeltreffendheid, op alle terreine - die beste gehalte en dienste, vroeg en laat. Laat ons nie verval in prosaiese ongeërgdheid wat vandag in sekere leidende Westerse lande so algemeen opgemerk word nie.

Elke land probeer om sy posisie in die snel veranderde wêreld van vandag te versterk en te verbeter. As gevolg van hierdie proses het mededinging op alle terreine wêreldwyd verskerp. Mededinging erken vandag geen landsgrense nie. Daar lê dus vir ons 'n groot uitdaging voor waarop ons voorbereid moet wees. Hier is ' $n$ praktiese voorbeeld om ons tot nadenke te stem: Brittanje is besig om veld te verloor teenoor buitelandse maatskappye wat op sy eie bodem besig is om die Britte verby te steek. Dit blyk dat:

$\diamond$ Die produktiwiteit van buitelandse ondernemings in Brittanje $18 \%$ hoër is as dié van Britse ondernemings self.

$\diamond$ Buitelandse ondernemings in die afgelope aantal jare $51 \%$ meer op hul beleggingskapitaal verdien het as die Britse maatskappye.

$\diamond$ Die afset van buitelandse ondernemings in Brittanje met $80 \%$ toegeneem het gedurende 'n onlangse vyfjaar-tydperk, terwyl die totale afset van alle fabrikante gedurende dieselfde tydperk met slegs $23 \%$ toegeneem het. Gaan ons 
toelaat dat dit hier by ons ook gebeur?

(iv) En dan die heel belangrikste, arbeidsaamheid - om harder te werk, fisies en skeppend! Dit word gesê dat toe die eens glorieryke Romeine die hardste gewerk het, hulle die welvarendste nasie van die wêreld was, maar toe hulle op hulle gemak en ongeërgd begin raak het en later slegs twee dae per week gewerk het, hulle ondergang spoedig gevolg het.

\section{Lesse uit die verlede}

As ons vandag in globale parspektief na die wêreld kyk, dan kom die vraag op of daar nie vir die Weste ,tekens aan die muur" van verval of terugval is nie. In plaas van beter en briljanter gehalte en diens, soos bv. in Japan en sekere ander, veral Oosterse lande, ondervind mens meer en meer die teenoorgestelde in sekere leidende Westerse lande.

Leer ons Suid-Afrikaners uit hierdie lesse? Kan mense werklik glo dat vir 'n jong land soos ons met sy wekroep tot ontwikkeling en geleenthede, ons ook al beperkings het oor hoe lank sekere mense, of hulle dit vrywilliglik wil doen of nie, mag werk? Is die Ooste nie besig om die Weste onder die stof te werk nie?

B. Die verstandige ontginning en benutting van ons natuurlike hulpbronne: Soos vroeër aangetoon, verkeer Suid-Afrika in die bevoorregte posisie om oor groot minerale- en ander natuurlike rykdomme te beskik. Dit maak die strewe na groter selfstandigheid soveel makliker. Maar daar kan die saak nie gelaat word nie.

\section{Goud}

Wat ons goud betref - dit is iets waaroor dit moeilik is om op die huidige tydstip te veel te praat, veral waar die owerhede klaarblyklik met belangrike onderhandelings besig is wat betref die monetêre aspekte en bemarking van goud. Wat my persoonlik egter lankal in verband met ons goudproduksie hinder, is dat ons te veel en te lank by die tradisionele afsetkanale bly en dat ons ons ekonomiese ontwikkelingsprogram te lank en te grootliks deur "goudaspekte” laat beinvloed.

Ek glo dat goud, behalwe moontlike heel tydelike skommelinge, nie alleen sy waarde sal behou nie, maar dat dit in 
die groter, ryker wordende wêreld wat ons tegemoetgaan, al meer 'n gesogte metaal sal word. Persoonlik sou ek graag wou sien dat ons minstens 'n deel van ons goud aanwend in 'n goudverwerkingsbedryf en dit op 'n heel gediversifiseerde grondslag in die wêreld bemark. Verkoop ons nie hierdie kosbare metaal van ons te gou teen té lae pryse uit nie? Verder is dit hoog tyd dat ons in ons ekonomiese beplanning goud meer apart of as iets addisioneel sal beskou en nie toelaat dat dit ons ekonomiese en finansiële beplanning en beleid van dag tot dag in só 'n groot mate beïnvloed as wat wel tot dusver die geval was nie.

\section{Ander minerale}

Die grootste gedeelte van ons ander natuurlike hulpbronne is tot nog toe onontgonne, alhoewel ons reeds die wêreld se vierde grootste produsent van alle minerale is. Ten opsigte van ontginning is Suid-Afrika dus 'n wêreldleier, en ons reserwes is so groot dat hul nie in die afsienbare toekoms uitgeput sal raak nie. Maar, in ons strewe na selfstandigheid moet ons nie tevrede wees met slegs die ontginning en uitvoer daarvan nie. Ons moet as algemene beleid die verdere verwerkinge, veredeling en ook bemarking van die finale produkte daarvan nastreef en verwesenlik - m.a.w. ons moet arbeid daarby voeg en dan uitvoer en bemark! Die voordele is groot en veral belangrik, dit is ' $n$ belangrike stap in die rigting van ekonomiese selfstandigheid.

Ook, net soos in die geval van goud, is dit jammer om deur té vroeë, blote ontginning alleen, te veel van ons potensiële rykdom van die toekoms teen 'n té lae prys ",weg te gee".

C. Die skepping van die regte ontwikkelingsklimaat en doel om te presteer: Die mate waarin die Staat en die private ondernemer doelbewus saamwerk en die voorbeeld stel om „die regte klimaat" te skep, is 'n belangrike voorvereiste vir die behaling van ekonomiese en finansiële onafhanklikheid en weerbaarheid.

\section{Die ideaal - mik hoog en werk saam}

Dit is nodig omdat die grondslag van ons ekonomiese stelsel privaat kapitalisties is, waar die inisiatief grootliks aan die privaat persoon en die maatskappy, oorgelaat word en oorge- 
laat behoort te word, terwyl die primêre funksies i.v.m. infrastruktuur en breë beleidsvorming aan die Staat oorgelaat word. Die ideaal is dat van beide kante hoog gemik moet word en daar in 'n atmosfeer van hoë idealisme saamgewerk moet word.

\section{'n Nasionale filosofie}

Die strewe, ook na 'n volkome ekonomies selfstandige en weerbare Suid-Afrika, moet 'n nasionale filosofie wees wat van elke platform af verkondig word.

\section{Die ,uitwaartse beweging”}

In 'n aksieprogram vir hierdie belangrike taak is daar sekere beginsels en praktyke wat ons sal moet aanvaar. Sommige is maklik uitvoerbaar, ander nie so maklik nie, en daar is party wat selfs as „,afwykings" beskou sal word op die pad wat ons tot dusver in Suid-Afrika geloop het. Hier verwys ek na die sogenaamde uitwaartse beweging onder die leierskap van Sy Edele ons Eerste Minister. Ek stem volkome daarmee saam. Ek glo dat dit noodsaaklik is indien ons ons ideaal wil bereik.

Dan is daar ook sekere ander aspekte in dieselfde verband wat ek graag kortliks wil behandel:

D. Die behoud van en die veg vir 'n blywende vrye, kapitalistiese stelsel: Dit is die stelsel wat die maksimum vryheid van die mens verseker, hom aanspoor tot die hoogste prestasies, en wat elke belangrike groot en welvarende nasie sover gebou het. Landswette is nodig en a.g.v. ontwikkeling sal hulle steeds toeneem, maar, en hier wil ek my sienswyse baie duidelik stel, oorregimentasie en 'n oormaat van kontroles is uiters gevaarlik en sal agteruitgang en selfs ondergang kan beteken. Kontrole bring meer kontrole met al sy stygende koste van beheer en administrasie. Indien ons toelaat dat ons in burokrasie verval, sal ont ontwikkeling en ons ideale nie verwesenlik word nie. Dit is 'n kwaal waaraan juis Brittanje ly. Wil ons húlle navolg? Volg ons nie juis hierdie land gewoonlik te veel, byna slaafs na nie?

Dit mag geregverdig wees, maar dit skok mens tog om die syfers te lees wat heel onlangs deur 'n professor van die Universiteit van Suid-Afrika i.s. ons Staatsdiens aangehaal is. $\mathrm{Hy}$ 
het gemeld dat die Staatsdiens se getalle van 1937 tot 1966 met $276 \%$ toegeneem het. In dié tyd het die blanke bevolking met net $70 \%$ toegeneem. As die tempo voortduur, sal die Staatsdienspersoneel tot 1980 met nog $72 \%$ toeneem terwyl die blanke bevolking met net $27 \%$ sal toeneem. Volgens vasgestel kon word, skyn hierdie ook die patroon te wees in 'n land soos Engeland, so lank reeds „op sy pad terug”.

Laat ons ook nie altyd die vinger na die Staat wys as verantwoordelik te wees vir alle nuwe wette nie. Die Staat bring dikwels slegs maar net die "wense" van die mense tot uiting. Ons as privaat persone en sakemanne is dikwels daaraan skuldig dat ons oor elke ding waarmee ons ontevrede is, na die Staat "hardloop" om wette te maak om dit te verbied en ons te beskerm. Wetgewing word ook te dikwels deur sakelui bepleit as ' $n$ verskansing teen gesonde mededinging. As die sakeman van vandag en van die toekons 'n ,,beskermingsmentaliteit" gaan openbaar, sal ons land ekonomies finansieel gesien waarskynlik bly mank gaan aan volkome selfstandigheid. Hiermee wil ek natuurlik nie te kenne gee dat ek nie ten gunste is van geregverdigde beskerming van ons jong en nog ,kleinskaal"-nywerhede en ander landseie instellings teen die "imperialisme" van matige en oud gevestigde buitelandse ondernemings nie. Tewens, hierdie vorm van beskerming is nog 'n noodsaaklikheid op ons pad na selfstandigheid.

\section{Nuwe wette}

Is dit nie ook hoog tyd, en dit het ek al jare gelede begin bepleit, dat ons 'n "windstilte" van nuwe wette kry nie en dat ons ' $n$ jaar of wat neem net om reeds bestaande wette te hersien, te konsolideer en te moderniseer?

\section{Mededinging deur die staat}

Mededinging deur die Staat, direk en indirek, is nog 'n gevaar op hierdie gebied waarteen ons gedurig sal moet waak. Staats- en semi-staatsinstellings en die persone daaraan verbonde behoort nie toegelaat te word om met privaat inisiatief mee te ding en in moeilik versoenbare of gekompromitteerde posisies te beland nie. Ek dink dit is tyd dat ons die soeklig 'n keer skerp hierop laat val. 
E. Minstens gelykheid van geleentheid vir eie Suid-Afrikaanse instellings en owerheidsbeleid. Hierdie is ongelukkig 'n aspek wat, ek wil anneem noodgedwonge of onbewustelik, oor die afgelope aantal jare baie nadelig ingewerk het op ons eie jonger Suid-Afrikaanse en Suid-Afrikaans beheerde ondernemings. Hier dink ek nie net aan die beperkende monetêre en fiskale maatreëls wat getref is nie, maar in besonder aan die vorm waarin dit gedoen is.

Dit is ongelukkig so dat dit juis die eie Suid-Afrikaanse ondernemings, meesal die jong, die klein, die middelslag en die middelmatig groot ondernemings is wat meer afhanklik is van krediet as die ander oud gevestigde ondernemings met groot reserwes wat oor baie jare opgebou is, en waarvan baie nog direk en indirek van oorsee af beheer word. Uit praktiese ondervinding, ook veral onder geledere van die Afrikaanse Handelsinstituut, weet ons hoedat die besondere vorms van beperking oor die afgelope aantal jare nie alleen die groei en vooruitgang van hierdie tipe ondernemings beperk het nie, maar ook teweeggebring het dat baie van hulle oorgeneem is of geamalgameer het met ander groter ondernemings, dikwels minder landseie. Hierdie is ' $n$ ingewikkelde onderwerp wat op sy eie 'n noukeurige studie verg, maar ek is oortuig daarvan dat formules tog gevind kan word om minstens nie die mededingingsvermoë van ons landseie instellings so nadelig te tref nie.

Maatreëls soos die huidige dogmatiese plafon op bankkrediet ontwrig die ekonomie en die mededingingsvermoë van die verskillende ondernemings te veel en behoort vervang te word met 'n meer wetenskaplike en billike vorm van beheer, soos eweredig verhoogde reserwe- en likiede bate-verhoudings ooreenkomstig die aard en termyn van die fondse in die besit van al die verskillende instellings. Ook behoort meer van bv. staatslenings gebruik gemaak te word om surplus-likwiditeit weg te dreineer.

Daar kan verder ook baie meer aandag gegee word deur owerheids- en semi-owerheidsinstansies om doelbewus Suid-Afrikaanse en Suid-Afrikaans beheerde instellings te ondersteun en aan te moedig. Hierdie voorbeeld word tewens deur ander leidende lande van die wêreld vir ons daargestel.

F. Die stel van hoë ekonomiese doelwitte met die aksent 
op die oorkoming van struikelblokke liewers as om moontlike groei te verlangsaam om struikelblokke op só 'n negatiewe manier te oorkom:

Hierdie aspek is reeds beklemtoon. 'n Groei-georiënteerde land soos Suid-Afrika behoort nie teruggehou te word omdat daar swaar druk op sy verskillende produksiefaktore ontstaan nie. Hier dink ek meer in besonder aan wat ek as ons grootste knelpunt beskou, nl. ons arbeidskragtekort. Liewers as om ekonomiese vooruitgang terug te hou, kan veel meer bereik word deur, onder andere, 'n baie lewenskragtiger benadering tot en aanmoediging van immigrasie, hersiening en vaartbelyning van ons vakleerlingstelsels, die hersiening en aanpassing van ons belastingstelsel om harder werk aan te moedig liewers as om dit te ontmoedig, doelbewuste aanmoediging deur belastingtoegewings ten opsigte van meganisasie en outomatisasie en baie groter beklemtoning van opleiding, ook in fabrieke en sake-ondernemings in die algemeen.

G. Opvoeding en navorsing: Opvoeding en navorsing moet die hoogste prioriteit in die beplanning van ons selfstandige toekoms geniet. Eén van die belangrikste vereistes is dus dat ons alles in ons vermoë moet doen om die brein- en skeppingskrag van al ons mense aktief en lewenskragtig te ontwikkel. Ons spandeer glad te min hieraan. Oit is een gebied waar ons nooit en onder geen omstandighede moet probeer „,bespaar” nie. Hoe kan ons in elk geval wil bespaar op 'n belegging wat die "grootste opbrengs" van alle beleggings lewer? Dit is die belegging in die menslike materiaal, die brein, skeppingskrag as produksievermoë van ons volk.

Ek glo dat die nasies wat in opvoeding en navorsing die toon aangee en voorbly om dit te doen, die beste kans het om die leidende nasies in die toekomstige wêreld te bly of te word. Daar is by my geen twyfel nie dat, indien ons ons volk die bes opgevoede, vry en die hoogs beskaafde kan maak, en geinspireerd en hardwerkend kan hou, ons die leiers en die welvārendste volk van die toekomstige wêreld kan word, nog in die leeftyd van die meeste van ons. Dit sal baie nugtere denke, hoë doelwitte en harde, fisiese en skeppende werk verg! Maar, „dit alles" kan baie genotvol wees. Die mens is die gelukkigste as hy hard werk vir hoë ideale! Kaapstad.

Jan S. Marais. 